\title{
Rozvoj flexibility jako komponenty zdravotně orientované zdatnosti
}

\section{Development of flexibility like component of health related fitness}

\author{
Hana Kabešová
}

\author{
Pedagogická fakulta Univerzity Jana Evangelisty Purkyně, Ústí nad Labem
}

\begin{abstract}
Abstrakt
Práce se zaměruje na problematiku flexibility scílem podat přehled poznatků o rozvoji a diagnostice flexibility $v$ rámci zdravotně orientované $z$ datnosti. Zdưrazňuje se dủležitost udržení optimální úrovně flexibility a zvyšování sniženého rozsahu pohybu v kloubně svalové jednotce. Studie podrobně rozpracovává výsledky vědeckých prací porovnávajících účinky jednotlivých metod strečinku a zpi̊soby rozvoje pohyblivosti u zdravých jedincù $v$ tělovýchovné praxi. K udržení optimální pohyblivosti se doporučuje začleňovat protahovací cvičení, zvyšující celkovou tělesnou zdatnost, do dlouhodobého pohybového programu. $V$ závěru jsou shrnuta doporučení vyplývající z metodiky protahovacích cvičení zaměrených pro rozvoj pohyblivosti. Jako pro začátečníky efektivní se jeví použití statické metody strečinku, u jedinců s vy̌šsi úrovní výkonnosti je vhodné aplikovat metody PNF.
\end{abstract}

\begin{abstract}
This article is dedicated to problems of flexibility with the aim to provide review of development and diagnostic of flexibility in terms of health related fitness. It justifies importance of the equilibration of optimal level of flexibility and increasing of reduced range of motion in the joint-muscle unit. This study elaborates the results of scientific works comparing the effects single stretching methods and varieties of flexibility's development by healthy persons in physical training. To maintain optimal flexibility is commend integration of stretching exercise into long-term motion intervention program upping fitness. As effective for the beginners appear static stretching method, for persons with higher performance is suitable the aplication of PNF methods.
\end{abstract}

Klíčová slova: $\quad$ zdravotně orientovaná zdatnost, flexibilita, rozvoj a hodnocení pohyblivosti Keywords: $\quad$ health related fitness, flexibility, development and evaluating of flexibility

\section{Úvod}

V popředí zájmu dnešní doby stojí problém hypokineze a nezdravého způsobu života. Zdravotně orientovaná zdatnost souvisí s pojmem zdraví, přičemž péče o zdraví by měla probíhat zlepšováním životního stylu. Provozování pohybových aktivit zlepšuje zdraví a relativně zvyšuje výkonnost a zároveň poskytuje radost a zábavu. Tělesná cvičení se doporučuje provádět do takového zatížení, které neovlivňuje schopnost přijímat estetické podněty vnějšího prostř̌edí a nesnižuje intenzitu prožitku.

Většina sportovních soutěží je dnes zaměřena výkonnostně a od jedinců se očekává podávání vrcholných sportovních výkonů, což nevyhovuje masovému provádění. Výkonnostní požadavky se vzdálily nenáročnému provádění aktivit a rozsah tréninků zaplnil upravené prostory sportovních ploch, hal a tělocvičen.

Obecně bychom mohli říci, že v dnešní době dochází ke zmenšování rozsahu pohybu v důsledku adaptace organismu na snížené nároky moderního způsobu života, proto má rozvoj pohyblivosti zásadní význam při předcházení funkčních poruch.

Flexibilita je důležitá především z hlediska správného držení těla a dosažení plného funkčního zdraví zejména v dospělosti. Dostatečná úroveň flexibility zvyšuje možnosti efektivního motorického učení, zajištuje ekonomičnost pohybů, menší riziko zranění a obecně vede $\mathrm{k}$ bezproblémovému provádění pohybových aktivit každodenního života. Menší odchylky v rozsahu pohyblivosti mohou způsobit dílčí omezení pohybového aparátu a později přerůst v poruchu pohybového aparátu. Význam flexibility shr- 
nuje Pistotnik (1998) do sedmi bodů: úspěšné ovládnutí techniky pohybu, větší ekonomičnost pohybu, estetická forma pohybového projevu v některých sportech, menší pravděpodobnost postižení či zranění, zábrana defektů $\mathrm{v}$ držení těla, ovlivnění ostatních motorických schopností a bezproblémové provádění pohybové aktivity každodenního života.

Flexibilitu charakterizujeme ve vztahu ke zdravotně orientované zdatnosti, nebot' testy pohyblivosti jsou součástí nejznámějších baterií testů, zjištujících celkovou tělesnou zdatnost. Jsou obsaženy např. ve známém Kraus-Weberově testu nebo v baterii testů podle Fleishmana. Zvýšený zájem o flexibilitu v USA vyvolaly výsledky měření zdatnosti mládeže přednesené na konferenci „President's Conference on the Fitness of American Youth “, kde v testu doteku země v předklonu neuspělo 44,3\% mládeže, zatímco v Evropě jen 7,8 \% (Kraus a Hirschland, 1954).

\section{Koncepce zdravotně orientované zdatnosti}

Pro začlenění komponenty flexibility bylo nutné nejprve vymezit pojem zdravotně orientované zdatnosti a charakterizovat ostatní pojmy související s tématem. Následně je nastíněna koncepce zdravotně orientované zdatnosti a kloubní pohyblivost je specifikována jako jedna z jejích komponent.

Pojem zdatnost je chápán jako připravenost organismu konat práci bez specifikace, o jakou formu práce se jedná, nebo jako schopnost člověka vyrovnávat se s vnějšími nároky, respektive odolávat aktuálním vlivům okolí (Bunc, 2006). Součástí obecné zdatnosti je nespecifická potenciální adaptace na pohybovou zátěž, nazývaná tělesná zdatnost. Tělesná zdatnost spolu s pozitivním př́stupem k životu, osobními návyky, výživou spojenou s kontrolou hmotnosti a zvládnutím stresu tvoří podle Blahušové (2005) podstatu tzv. „wellness“.

Tělesná zdatnost je pojem s dlouhou historií hledání popisu a výběru parametrů. Přehled definic tělesné zdatnosti do konce 90 . let minulého století publikoval Pate (1988). V současné době se do popředí dostává koncepce, která rozlišuje zdravotně orientovanou a výkonově orientovanou zdatnost.

Pojem zdravotně orientovaná zdatnost (health-related fitness) je definován jako zdatnost ovlivňující přímo či nepř́mo zdravotní stav jedince vztahující se k dobrému zdravotnímu stavu a působící preventivně na zdravotní problémy spojené s hypokinézou (Corbin a Pangrazi, 1992). Zdravotně orientovaná tělesná zdatnost se může ve svém důsledku projevovat jako úroveň kvality života (well-being), která nám dovoluje vykonávat nezbytné každodenní aktivity kvalitně a s vysokým nasazením, redukovat výskyt některých zdravotních problémů, zvládat náročné činnosti nerealizovatelné bez dostatečné zdatnosti, ovlivňovat psychiku pozitivními prožitky a přispívat obecně k plnějšímu prožití života (Bunc, 1995; Morrow et al., 2005). Velmi důležité je učit už děti, jak zdokonalovat a udržovat zdravotně orientovanou zdatnost.

Koncepce zdravotně orientované zdatnosti v tabulce 1 obsahuje pět komponent: morfologickou, svalovou, motorickou, kardiorespirační a metabolickou (Bouchard a Shepard, 1994). Koncepce má spíše účelový než př́sně vědecký charakter.

Tab. 1 Komponenty zdravotně orientované zdatnosti (Bouchard a Shepard, 1994; u nás publikoval Kovář, 2001)

\begin{tabular}{|c|c|c|c|c|}
\hline $\begin{array}{c}\text { 1. Morfologická } \\
\text { komponenta: }\end{array}$ & $\begin{array}{c}\text { 2. Svalová } \\
\text { komponenta: }\end{array}$ & $\begin{array}{c}\text { 3. Motorická } \\
\text { komponenta: }\end{array}$ & $\begin{array}{c}\text { 4. Kardiorespirační } \\
\text { komponenta: }\end{array}$ & $\begin{array}{c}\text { 5. Metabolická } \\
\text { komponenta: }\end{array}$ \\
\hline $\begin{array}{c}\text { relativní tělesná } \\
\text { hmotnost }\end{array}$ & $\begin{array}{c}\text { explozivní } \\
\text { síla }\end{array}$ & flexibilita & $\begin{array}{c}\text { submaximální } \\
\text { pracovní kapacita }\end{array}$ & glukózová tolerance \\
\hline složení těla & $\begin{array}{c}\text { maximální } \\
\text { síla }\end{array}$ & rovnováha & $\begin{array}{c}\text { maximální } \\
\text { aerobní kapacita }\end{array}$ & $\begin{array}{c}\text { citlivost } \\
\text { na inzulín }\end{array}$ \\
\hline $\begin{array}{c}\text { rozložení } \\
\text { podkožního tuku }\end{array}$ & vytrvalost & koordinace & oběhové funkce & $\begin{array}{c}\text { krevní lipidy } \\
\text { lipoproteidy }\end{array}$ \\
\hline hustota kostí & rychlost & ventilační funkce & $\begin{array}{c}\text { charakteristika } \\
\text { oxidace substrátů }\end{array}$ \\
\hline & & krevní tlak & \\
\hline
\end{tabular}


Hodnocení úrovně zdravotně orientované zdatnosti se posuzuje především pomocí jejích jednotlivých komponent. Ǩada autorů mezi základní komponenty řadí: aerobní zdatnost, tělesné složení, svalovou sílu a vytrvalost (svalově-kosterní zdatnost) a flexibilitu (Bunc 1995, Welk et al., 2002). Hodnocené faktory lze rozdělit na strukturální a funkční, přičemž mezi funkční se zařazuje navíc držení těla v základních posturálních polohách a kvalita pohybových stereotypů (Bursová a Rubáš, 2001; Zítko et al., 2003).

\section{Komponenta flexibilita}

Blíže se zaměříme na jednu z motorických komponent - flexibilitu, nebot její nedostatečná úroveň může být limitujícím faktorem při provádění tělesných cvičení. Je důležité udržovat optimální úroveň pohyblivosti, nebot změny ve funkci svalu probíhají ve vazbě na funkční změny v oblasti kloubu. Pohyb je způsoben vzájemným působením svalstva a skeletu, tedy sval vytváří při svém stažení napětí, které je pomocí šlach přenášeno na kosti (Alter, 1999). Hovoří se o kloubně-svalové souhře (Novotná, 2006).

Flexibilita (kloubní pohyblivost) je definována jako schopnost vykonávat $\mathrm{v}$ určitém kloubu nebo v kloubním systému plynulé pohyby v náležitém rozsahu, lehce a požadovanou rychlostí (Choutka a Dovalil, 1987; Měkota a Novosad, 2005; Alter, 1999; Blahušová, 2005). Flexibilita se zařazuje mezi schopnosti kondičně-koordinační, tzv. hybridní, nebot’ se uplatňuje jak v kondičních, tak i koordinačních schopnostech (Havel a Hnízdil, 2010).

Rozsah pohybu v kloubu je omezen kloubním pouzdrem (47 \%), svalstvem (41 \%), šlachou (10\%) a kủží (2\%) (Bunc, 1995).

Mezi další faktory, které mají vliv na rozsah pohybu v kloubu, patří aktuální psychický stav, únava, věk, teplota prostředí, kvalita rozcvičení aj. (Buzková, 2006).

\subsection{Rozvoj flexibility - způsoby rozvoje}

Flexibilita se v průběhu života mění. Každý kloub má jinou úroveň flexibility. Není to obecná složka fitness jako vytrvalost nebo síla, jedná se o specifickou pohybovou schopnost. Člověk může mít v jednom kloubu optimální pohybový rozsah, zatímco v jiném špatný. O flexibilitě se může hovořit v souvislosti s pohybem pouze v jednom kloubu, jako je např́iklad koleno, nebo pohybem zahrnujícím sérii kloubů, jako je např́klad páteř při rotaci trupu (Blahušová, 2005). Z tohoto důvodu se flexibilita dělí podle jednotlivých částí těla: flexibilita paží, ramen, trupu, nohou, kyčlí apod. (Mrakovič et al., 1996; Bouchard et al., 1997; Kasa, 2001; Malina et al., 2004).

Při porovnání pohyblivosti u mužů a žen „vykazují ženy v průměru vyšší flexibilitu než muži v důsledku anatomických a fyziologických diferencí mezi pohlavími, týká se to zejména pánevní oblasti“ (Měkota, 2005: 97).

V dětství se flexibilita rozvíjí snadněji než v dospělosti, do puberty flexibilita klesá a narůstá opět $\mathrm{v}$ období adolescence. Ačkoli je pohyblivost značně geneticky determinována $\left(h^{2}>0,6\right)$, můžeme ji značně ovlivnit cvičením. Některé studie ukázaly významné ovlivnění výsledných dat růstovými změnami $\mathrm{v}$ dětství v souvislosti se změnou poměru délek končetin a trupu (Docherty, 1996).

Senzitivní období pro rozvoj flexibility je 7 až 11 let (Kasa, 2001; Měkota, 2005). Vhodné je rozvíjet flexibilitu zejména pro pozdější věk v dospělosti, kdy pohyblivost postupně klesá. Dřivější práce prokázaly, že maxima rozsahu pohyblivosti se dosahuje kolem 23 let, potom následuje pozvolný úbytek a kolem 65 se objevuje náhlé zhoršení. U pravidelně cvičících je tento zlom posunut až o 10 let později (Kuta a Eiselt 1965; Buddeusová, 1967).

V praxi se setkáváme ponejvíce s hypomobilitou, jejíž korekce spočívá v protažení zkráceného (nejčastěji tonického) svalu a následném posílení př́slušného antagonisty (nejčastěji fázického) (Docherty, 1996; Welk et al., 2002; Měkota, 2005). Hypermobilita v kloubních spojeních je méně častá (odhlédnemeli od hypermobility záměrně stimulované z důvodu sportovní výkonnosti). Možnost korekce je v cíleně zaměřených posilovacích cvičeních. Se znalostí svalů s tendencí k oslabování a svalů s tendencí ke zkrácení můžeme vhodnými prostředky a metodami intervenovat ve směru dosažení optimálního fyziologického rozsahu (Hnízdil, 2003). Při usměrňování pohyblivosti musíme současně působit na všechny roviny hybného systému, je nutné se zaměřit i na ovlivnění funkčních možností CNS (Kolář, 1996). Je 
třeba respektovat a správně využívat nervosvalové mechanismy, tj. strečinkový reflex, inverzní myotatický reflex a reciproční inervaci.

Cílem cvičení pro rozvoj kloubní pohyblivosti je zajistit individuálně optimální amplitudu pohybů celého pohybového aparátu vzhledem $\mathrm{k}$ anatomicko-fyziologickým možnostem pohybového systému a potřebám jedince. Žádaných cílů se dosahuje kombinací relaxačních, mobilizačních, protahovacích a posilovacích cvičení.

Předpokladem efektivního protahování svalů a vazů je uvolnění svalů (relaxace), optimální reflexní aktivita svalů a odpovídající síla agonistů zajištující dosažení krajní polohy. Mezi uvolňovací cvičení patří protřepávání, kývání, kroužení a náročnější techniky, např. založené na vědomé kontrole svalstva - vnímání kontrakce a relaxace (Jacobson) nebo navozování pocitů tíhy, tepla (Schulzův autogenní trénink).

Protažením svalů se dosahuje krajních poloh $v$ příslušných kloubech. Při protahovacích cvičeních se zaměřujeme spíše na sval a jeho fascie obsahující více elastického vaziva než na vazy a šlachy, u nichž je nadměrné prodloužení struktury nežádoucí a může vést $k$ narušení funkčnosti a destabilizaci kloubů (Alter, 1999). Protahovací cvičení se provádí u odpočatých a koncentrovaných sportovců, po dokonalém rozcvičení (prohřátí). Při volbě metod protahování (druhu, trvání, náročnosti) je třeba vycházet ze stavby a funkcí podpůrně-pohybového aparátu, požadavků sportovního výkonu a individuálních specifik (stereotypy v držení těla, stav svalových skupin, mimotréninková činnost, aj.) Upřednostňuje se pomalé statické protahování, tzv. strečink, před švihovým protahováním, zvláště u začátečníků a na konci tréninkové jednotky.

Způsoby protahování podle Havla a Hnízdila (2010) členíme podle sil, které zajištují dosažení krajní polohy, na pasivní a aktivní. Při pasivním protahování je krajní polohy dosaženo vnější silou, podmínkou je provádět je opatrně a měkce. Při aktivním protahování je krajní polohy dosaženo vlastní silou. Další členění vychází z dynamiky provedení pohybu. $\mathrm{V}$ dynamickém provedení je dosaženo krajních poloh švihy nebo hmity (eventuelně s krátkou výdrží). Provádí se měkce, ale nedoporučují se provádět u začátečníků. Opakem jsou cvičení statická s výdrží 10-30 s v krajní poloze. Způsoby lze kombinovat.

Soubor protahovacích cvičení zaměřených na určitý sval či svalovou skupinu, při nichž dochází k prodlužování vazivové tkáně, svalů a dalších tkání, se označuje pojmem strečink (Alter, 1999). Ačkoli se podobná tělesná cvičení objevovala už v historických systémech v Indii, v Číně a Japonsku, získala aplikace protahovacích cviků, připomínajících metody rehabilitace, velký ohlas, oblibu a široké uplatnění až dnes.

Cílem strečinku je připravit jedince $\mathrm{k}$ podání sportovního výkonu, kompenzovat jednostranné zatížení a aktivně regenerovat po zatížení (v intervalech odpočinku mezi cvičením dochází k okysličení tkání spojenému s odplavením metabolitů, uvolnění; protažení tkání provádíme nižší intenzitou, měkce s výdrží do $30 \mathrm{~s}$ ) a zvyšovat pohyblivost. Cílem strečinku není působit na bezduchý pasivní materiál, ale na aktivitu napínacího reflexu a gama-systému - utlumit je (Šebej, 1989).

Podle Šebeje (1989) je možné metody strečinku rozdělit do dvou kategorií. První je statická metoda strečinku propagovaná $B$. Andersonem, druhou kategorii tvoří metody označované ve sportovní literatuře PNF metody. Proprioceptivní neuromuskulární facilitace (PNF) je strečinková technika vycházející z fyzikální terapie. K zvýšení rozsahu pohybu, zlepšení výkonu a snížení rizika poranění využívá při protažení svalu reflexních mechanismů (reflexního útlumu a reciproční inervace). Jedná se o Holtovu metodu 3-S, metodu propagovanou S. Sölvebornem a další metody PNF. Jednoznačně jsou vymezené metody: metoda B. Andersona, nazývaná statická nebo klasická metoda, Holtova metoda 3-S a Sölvebornova metoda.

Při statickém strečinku se sval pozvolna protahuje s prodlouženým výdechem do krajní polohy s výdrží 10-30 s. Statická metoda B. Andersona rozlišuje tři stupně protažení - lehké protažení (easy stretch), rozvíjející protažení (developmental stretch) a drastické protažení (drastic stretch) - k tomuto stupni by při strečinku nemělo dojít.

Holtovu metodu 3-S lze charakterizovat izometrickou kontrakcí agonisty (5-7 s), po které následuje po uvolnění (2-3 s) koncentrická kontrakce antagonisty (5-7 s). 
Metoda podle Sölveborna využívá poznatku snížení tonu svalu po izometrické kontrakci, kdy sval kontrahujeme proti odporu (10-30 s), uvolníme (2-3 s) a plynule měkce protáhneme (minimálně $30 \mathrm{~s}$ ).

PNF techniky podle Dostálové a Miklánkové (2005) mají několik variant. V první technice protažení po kontrakci agonisty dochází ke koncentrické aktivaci agonisty (vzrůst svalového napětí 7-10 s), následuje uvolnění (2-3 s) a potom protažení svalu po dobu 10-15 s spojené s výdechem. Druhá technika s využitím postizometrické kontrakce agonisty využívá izometrické aktivace svalu (vzrůst svalového napětí proti odporu), následuje uvolnění a pasivní protažení spolucvičencem, spojené s výdechem. Využívá se bud' techniky postizometrické relaxace PIR, kde je izometrické napětí minimální a protažení velmi šetrné, nebo techniky postizometrického protažení PIP, kde izometrické napětí je poměrně vysoké a následné protažení důraznější. Třetí technika využívá reciproční inervace tak, že při protahování je současně aktivován antagonista (sval působící opačně) nebo je nejprve izometricky aktivován antagonista (5-7 s), a pak následuje protažení agonisty (15-20 s).

Obdobně rozeznává pět základních technik strečinku Alter (1999): statický, dynamický, pasivní, aktivní a proprioceptivní strečink.

Strečink ve vztahu ke cvičení pro rozvoj kloubní pohyblivosti lze definovat následovně: dynamický strečink - aktivní dynamická cvičení, statický strečink - aktivní statická cvičení, pasivní strečink pasivní dynamická cvičení, aktivní strečink - pasivní statická cvičení (Novotná, 2006).

Statická metoda strečinku je základem protahovacích cvičení a je vhodným úvodem do strečinku, připraví svaly na náročnější cvičení. Metody spočívající na principu PNF jsou určeny pro aktivní, výkonnostní a vrcholové sportovce a mohou doplňovat ostatní protahovací techniky.

\subsection{Výsledky výzkumných prací zaměřených na rozvoj flexibility}

V popředí zájmu stojí otázky metodiky a účinků cvičení zaměřeného na rozvoj pohyblivosti. Při výběru je vždy nutné individuálně přihlédnout $\mathrm{k}$ dispozicím cvičence, zdravotnímu stavu, věku, pohlaví, tělesné zdatnosti, vrozeným dispozicím a aktuálnímu stavu.

Z protahovacích cvičení jsou doporučována cvičení statická oproti dynamickým. Bandy, Irion a Briggler ve výsledcích své studie (1998) uvádí, že 30sekundový statický strečink přináší dvakrát vyšší efekty zvýšení pohyblivosti než technika DROM (dynamic range of motion - dynamická cvičení ke zvýšení pohyblivosti).

Obdobných výsledků dosáhla studie (O'Sullivan, Murray a Sainsbury, 2009) posuzující krátkodobý efekt zahřátí, statického a dynamického strečinku na pohyblivost hamstringů u zdravých jedinců a jedinců po předchozím zranění hamstringů. $U$ obou skupin statický strečink i zahřátí signifikantně zvyšují flexibilitu hamstringů, zatímco dynamický strečink ne.

Výzkumné práce prokazují, že dynamický strečink sice vede k rozvoji optimálního rozsahu pohyblivosti nezbytnému pro všechny druhy sportů (Alter, 1999), avšak tato technika představuje nejdiskutovanější strečinkovou techniku z důvodu spuštění napínacího reflexu (Novotná, 2006) a následného výskytu bolestivosti svalů a poranění. Dynamický strečink není doporučován pro nesportující populaci.

Švihových pohybů lze využít ve specifických cvičeních, ale musí být sestaveny se zřetelem k zvolenému sportu a sportovci. Pro zvýšení dynamické pohyblivosti se doporučuje postupný program zvyšování rychlosti a rozvoje pohyblivosti po předchozím rozcvičení (Zachazewski, 1990).

Řeší se otázka vzájemného poměru užití statických a dynamických cvičení ve speciálním tréninku pohyblivosti. Aplikovat pouze statické strečinkové stereotypy není vhodné, protože nelze vyloučit jejich „potenciálně nepř́íznivý účinek na svalovou výkonnost“ (Rosenbaum a Henning, 1995). Kurz (1994) zpochybňuje teorii, že po počátečním rozcvičení by se měl provádět statický strečink, jelikož provádění statických strečinkových cviků před tréninkem tvořeným dynamickými pohyby je kontraproduktivní.

Strečink je metodou šetrnější a účinnější než dynamické protahování, protože je při něm menší pravděpodobnost ruptur svalových vláken (Měkota, 2005).

Proprioceptivní nervosvalová facilitace je odborníky hodnocena a považována za nejefektivnější strečinkový systém. Výzkum Holta, Travise a Okity (1970) se zabýval porovnáním okamžitého účinku jednotlivých metod strečinku (statického, dynamického a PNF) měřením bezprostředně po cvičení. Dospěli 
k závěru, že všechny metody PNF se ukázaly být účinnější než všechny ostatní metody strečinku. Mezi další jejich závěry patří, že mezi metodami PNF je pravděpodobně nejúčinnější Holtova metoda 3-S, ale je velmi náročná a nelze ji použít ve všech rovinách pohybu.

Obě metody systému PNF (Sölvebornova i pasivní) se ukázaly efektivnější než statická metoda (Strešková, 2007). U všech tří zmíněných metod bylo u dívek zjištěno zlepšení pohyblivosti se statistickou významností p $<0,05$ (Strešková, 2007).

Ve studii Cornelia, Ebrahima, Watsona a Hilla (1992) se zjistily významné rozdíly mezi technikami zvyšujícími rozsah pohybu ROM ( $\mathrm{p}<0,05)$, kdy post hoc analýza odhalila, že tři modifikované PNF techniky (PCP, 3-PIECP, 3-PIFCP) vykazovaly významnější zvětšení rozsahu pohybu než technika pasivního strečinku.

Oproti tomu však bylo konstatováno, že aktivní strečink a PNF v jednom opakování po dobu 30 $\mathrm{s} v$ průběhu tří dnů $\mathrm{v}$ týdnu nejsou dostatečně významné k prodloužení délky hamstringů u zkoumané populace dospělých ve věku 21-35 (Davis et al., 2005). Ukázalo se, že porovnáním účinku tří strečinkových technik (aktivní strečink, statický strečink a PNF) na délku hamstringů během čtyřtýdenního tréninkového programu při užití všech technik strečinku $(\mathrm{p} \leq 0,05)$ vzrostla délka hamstringů od základní hodnoty, avšak u skupiny ovlivněné statickým strečinkem byl výsledek významně větší než u kontrolní skupiny (Davis et al., 2005).

\subsection{Diagnostika flexibility}

Předmětem diagnostiky v této oblasti je především fyziologický rozsah jednotlivých kloubních spojení a fyziologický rozsah páteře.

Existuje řada postupů, které měří rozsah pohybu jednotlivých kloubů a kloubních spojení. Mezi nejpoužívanější patří kontrolní cviky, tzv. testy pohyblivosti. Ačkoli Falize (in Kos, 1964) tyto testy odmítá pro nedostatečnou přesnost, testy vykazují vysoký koeficient spolehlivosti. Dřívější práce publikují $r$ = 0,89-0,99 (Kos, 1964), Plowman (1995) u testu dětí školního věku uvádí spolehlivost v rozpětí 0,93 až 0,98 . Suchomel (2004) určuje koeficient reliability u stejně starých dívek $r=0,89$. U motorického testu hloubka předklonu v sedu odpovídá spolehlivost testu $r=0,97$ (Měkota, Blahuš, 1983). Měření flexibility testem předklon v sedu je tradiční součástí testových baterií zdravotně orientované zdatnosti již od 80. let minulého stolení. Důvodem jeho zařazení byl hypotetický vztah mezi bolestmi dolní části zad a flexibilitou dolní části zad a hamstringů (Aahperd, 1980). Kos (1964) ověřoval reliabilitu různých kontrolních cviků v období jednoho týdne za stejných podmínek a korelace mezi prvním a druhým měřením se pohybovala mezi 0,95 až 0,97 , přičemž statistická významnost rozdílu byla nepatrná 0,26 až 1,23 . Další jejich výhodou je praktické využití v tělovýchovné praxi.

Koeficient spolehlivosti $r=0,95$ je poměrně vysoký také u metody měření distancí, které se využívá zvláště při zjištování pohyblivosti ramenního kloubu. Pomocí trigonometrie se převádí délkové hodnoty na hodnoty úhlové.

Snad nejznámější je měření úhlů goniometrií pomocí kloubních úhloměrů, tzv. goniometrů. Pro vědecký výzkum se však nehodí, protože jejich přesnost je nedostatečná (nepřesné přiložení úhloměru může způsobit chybu kolem 5 stupňů) (in Měkota, Novosad, 2005). Velikou přesnost vykazuje oproti tomu gravitační goniometr, kde $r=0,934-0,997$. Určitý problém stále představuje unifikace a přesná standardizace procedury.

Mezi metody vyžadující specializované laboratoře, kvalifikovaný personál a nákladné prrístroje spadá rentgenologická metoda, pantografická metoda, která podává informace o vztahu zakřivení páteře vzhledem k její pohyblivosti. Pro aktivní švihové pohyby je možno použít metody stroboskopické fotografie či kinematografie, které lze konat s přesností \pm 1 až 2 stupně.

\section{Závěr}

Problematika flexibility je v současné době značně aktuální, jelikož snížená pohyblivost (hypomobilita) s sebou přináši řadu omezení hybnosti, a naopak zvýšená pohyblivost (hypermobilita) způsobuje především destabilizaci kloubu. Vznikají tak poškozené chrupavky, dochází k přetěžování ligament, nastu- 
puje pohybová inkoordinace a neschopnost utvářet kvalitní pohybové stereotypy. Aby došlo ke zlepšení a udržení zdraví při provozování pohybových aktivit, je nezbytné udržet optimální úroveň pohyblivosti jedince. Protahovací cvičení a strečink by se měl proto začlenit do dlouhodobého programu zvyšujícího celkovou tělesnou zdatnost a stát se jedním ze základních prostředků pohybové výchovy díky svým účinkům - protažení zkrácených svalů, udržení optimálního rozsahu pohybu v kloubně svalové jednotce a zvyšování rozsahu při snížené pohyblivosti, předcházení nebo odstraňování svalových dysbalancí a aktivace nervosvalového systému.

Otázkou zůstává způsob aplikace protahovacích cvičení a využití různých metod strečinku. Většina autorů se shoduje, že metody pomalého protahování jsou bezpečnější a k pohybovému aparátu šetrnější nežli dynamické pohyby, kdy se využívá švihových pohybů a hmitů. Pro začátečníky je doporučována metoda statického protahování, tzv. Andersenova metoda. Použití PNF metod je vhodné pro pokročilé cvičence.

Protahovací cvičení a strečink lze zařadit mezi pohybové aktivity v rámci rozcvičení jako př́pravu hybného systému na další zátěž, kdy slouží jako prevence svalových poranění a dalších poranění pohybového aparátu, odstraňují nadbytečné napětí svalů. Uplatnit je lze v průběhu nebo na konci cvičení, kdy cviky pomáhají zklidnit organismus, omezit vznik bolestivosti svalů, nebo jako prostředek pro rozvoj flexibility, součást mobilizace, jako samostatné cvičení či v rámci psychorelaxace snižující svalové i psychické napětí.

Při cvičení pro rozvoj kloubní pohyblivosti nelze opominout další podstatné faktory, které mohou ovlivňovat účinky protahovacích cvičení jako je teplota místnosti, denní doba, věk jedinců, únava, rozcvičení a druh vykonávané aktivity. Zároveň je nutné respektovat fyziologické mechanismy a při tělesných cvičeních s nimi postupovat $\mathrm{v}$ souladu.

\section{Literatura}

AAHPERD. Health-related physical fitness test manual. 1st ed. Reston, VA: Aahperd, 1980.

ALTER, J. M. Strečink: 311 protahovacích cviků pro 41 sportů. 2. vyd. Praha: Grada Publishing, 1999. ISBN 80-7169-763-X.

BANDY, W. D., IRION, J. M., BRIGGLER, M. The effect of static stretch and dynamic range of motion training on the flexibility of the hamstring muscles. J Orthop Sports Phys Ther, 1998, vol. 7, n. 4, p. 295-300.

BEEBLE, B. B., MANN, C. L. A comparison of two warm-ups on joint range of motion.

J Strength Cond Res, 2007, vol. 21, no 3, p. 776-779.

BLAHUŠOVÁ, E. Strečink 333 cviků a 31 sestav pro všechny. Praha: Wellness E. B., 2005.

BOUCHARD, C., SHEPARD, R. Physical activity, fitness and health: The model and key concepts. In BOUCHARD, C., SHEPARD, R., and STEPHENS,T.. Physical activity, Fitness and Health. 1st ed. Champaign: Human Kinetics, 1994, p. 77-88.

BOUCHARD, C. et al. Genetics of fitness and physical performance. 1st ed. Champaign: Human Kinetics, 1997. ISBN 0-87322-951-7.

BUDDEUSOVÁ, N. Analýza vybraných ukazatelů zdatnosti cvičících a necvičících žen středního a staršího věku. Kand. dis. práce. Praha: FTVS - UK, 1967.

BUNC, V. Pojetí tělesné zdatnosti a jejích složek. Těl. Vých. Sport Mlád., 1995, roč. 61, č. 5, s. 6-9.

BUNC, V. Zdatnost. In NOVOTNÁ, V., ČECHOVSKÁ, I., BUNC, V. Fit programy pro ženy. Praha: Grada Publishing, 2006, s. 12-16. ISBN 80-247-1191-5.

BURSOVÁ, M., RUBÁŠ, K. Základy teorie tělesných cvičení. 1. vyd. Plzeň: ZČU, 2001. ISBN 80-7082-822-6. BUZKOVÁ, K. Strečink: 240 cvičení pro dokonalé protažení celého těla. Praha: Grada Publishing, 2006. ISBN 80-247-0948-1.

CORBIN, C., PANGRAZI, R. Are American children and youth fit? Res. Quart. Exerc. Sport, 1992, vol. 63 , no. 2, p. 96-106. 
CORNELIUS, W. L., EBRAHIM, K., WATSON, J., HILL, D. W. The effects of cold application and modified PNF stretching techniques on hip joint flexibility in college males. Res Q Exerc Spor, 1992, vol. 63, n. 3., p. 311-314.

DAVIS, D. S., ASHBY, P. E., McCALE, K. L., McQUAIN, J. A., WINE, J. M. The effectiveness of 3 stretching techniques on hamstring flexibility using consistent stretching parameters. J. Strength Cond. Res., 2005, vol. 19, no. 1, p. 27-32.

DOCHERTY, D. Field tests and test batteries. In DOCHERTY, D. (ed.). Measurement in pediatric exercise science. 1st ed. Champaign: Human Kinetics, 1996, p. 285-334.

DOSTÁlOVÁ, I., MIKLÁNKOVÁ, L. Protahování a posilování pro zdraví. Olomouc: HANEX, 2005. ISBN 80-85783-47-9.

HAVEL, Z., HNÍZDIL, J. Rozvoj a diagnostika koordinačních a pohyblivostních schopností. PF, Univerzita Mateja Bela v Banskej Bystrici, 2010. ISBN 978-80-8083-950-5.

HNÍZDIL, J. Zdravotně orientovaná zdatnost. Elektronický učební text [online]. Ústí nad Labem: PF UJEP, 2003. Publikováno 23.9.2010 [cit. 2010-09-15]. Dostupný z WWW: <http://pf.ujep.cz/ktv/hnizdil/ antropo/ZOZ/ZOZ.html>.

HOLT, L. E., TRAVIS, T. M., OKITA, T. Comparative Study of Three Stretching Techniques. Perceptual and Motor Skills. 1970, vol. 31, p. 611.

CHOUTKA, M., DOVALIL, J. Sportovní trénink. Praha: Olympia, 1987.

KASA, J. Športová kinantropológia: terminologický a výkladový slovník. 1. vyd. Bratislava: SVSTVŠ a FTVŠ UK, 2001. ISBN 80-968252-8-3.

KOLÁŘ, P. Funkční poruchy hybného systému. In KUČERA, M.et al. Pohyb v prevenci a terapii. Praha: Karolinum, 1996, s. 189-196.

KOS, B. Metody měření kloubní pohyblivosti v tělovýchovné praxi a ve vědeckém výzkumu. Teor. Praxe těl. Vých., 1964, roč. 12/11, s. 503-510.

KOVÁ̌̌, R. Tělesná aktivita, tělesná zdatnost a zdraví. Česká kinantropologie, 2001, roč. 5., č. 1., s. 49-57. KRAUS, H., HIRSCHLAND, R. Minimum muscular fitness tests in school children. Res. Quart. Exerc. Sport, 1954, vol. 25, n. 5, p. 178.

KURZ, T. Stretching scientifically: A quide to flexibility training. 3rd ed. Island Pond, VT: Stadion, 1994.

KUTA, I., EISELT, E. Vliv tělesných cvičení na kloubní pohyblivost mužů pokročilého věku při různém tělovýchovném režimu. Teor. Praxe těl. Vých., 1965, roč. 13, č. 1, s. 22-28.

MALINA, R. et al. Growth, maturation and physical activity. 2nd ed. Champaign: Human Kinetics, 2004. ISBN 0-88011-882-2.

MĚKOTA, K. Koordinační schopnosti a flexibilita. In MĚKOTA, K., NOVOSAD, J. (ed.). Motorické schopnosti. 1. vyd. Olomouc: UP, 2005. II. část, s. 55-113.

MĚKOTA, K., BLAHUŠ, P. Motorické testy v tělesné výchově. Praha: SPN, 1983.

MĚKOTA, K., NOVOSAD, J. Motorické schopnosti. Olomouc: FTK UP, 2005.

MORROW, J. et al. Measurement and evaluation in human performance. 3rd ed. Champaign: Human Kinetics, 2005. ISBN 0-7360-5540-1.

MRAKOVIČ, M. et al. Developmental characteristics of motor and functional abilities in primary and secondary school pupils. Kinesiology, 1996, vol. 28, no. 2, p. 62-70.

NOVOTNÁ, V. Flexibilita. In NOVOTNÁ, V. , ČECHOVSKÁ, I., BUNC, V. (ed.) Fit programy pro ženy. Praha: Grada Publishing, 2006, s. 32-36. ISBN 80-247-1191-5.

O'SULLIVAN, K., MURRAY, E., SAINSBURY, D. The effect of warm-up, static stretching and dynamic stretching on hamstring flexibility in previously injured subjects. BMC Musculoskelet Disord, 2009, vol. 16 , no. 4, p. 10-37.

PATE, R. The evolving definition of physical fitness. QUEST, 1988, vol. 40, p. 174-189.

PISTOTNIK, B. Flexibility. In Antropomotorika 1998. Banská Bystrica. Vedecká spoločnost’ pre telesnú výchovu a šport 1998. 
PLOWMAN, S. Muscular strength, endurance and flexibility assessments. In WELK, G., ROSEMBAUM, D., HENNING, E. M. The influence of stretching and warm-up exercises on Achilles tendon reflex activity. Journal of Sports Science, 1995, vol. 13, no. 6, p. 481-490.

ROSEMBAUM, D., HENNING, E. M. The influence of stretching and warm-up exercises on Achilles tendon reflex activity. Journal of Sports Science, 1995, vol. 13, no. 6, p. 481-490.

STREŠKOVÁ, E. Efektívnost’aplikácie rozných metód strečingu. In Zborník z 5. roč. Konferencie Telesná výchova a šport na univerzitách. Nitra: Slov. polnohosp. univerzita, 2007.

SUCHOMEL, A. Př́spěvek ke standardizaci vybraných motorických testů baterie Fitnessgram. In SUCHOMEL, A., VOLF, M. Tělesná výchova a sport 2004, Liberec - Euroregion Nisa: Sborník příspěvků z mezinárodní vědecké konference - Liberec 24.-25.6. 2004. 1. vyd. Liberec: TU, s. 345-350.

ŠEBEJ, F. Strečing. Bratislava: Šport, 1989. ISBN 80-8065-019-5.

WELK et al. FITNESSGRAM reference quide [online]. 1st ed. Dallas: The Cooper Institute, 2002 [cit. 2010-09-16]. Dostupný z WWW: <http://fitnessgram.net/home/>.

ZACHAZEWSKI, J.E. Flexibility for sports. In SANDERS, B. (ed.). Sports physical therapy, 1990, s. 201-238.

ZÍTKO, M., BENEŠOVÁ, M., VEJRAŽKOVÁ, D., HROZA, J. Posouzení tělesné zdatnosti. Př́loha časopisu Pohyb je život [online]. 2003 [cit. 2010-09-16]. Dostupný z WWW: <http://www.csts.cz/www/clanky/dance/lit.htm>. 